\title{
METHODOLOGICAL BASIS OF THE FORMATION OF EFFECTIVE FORMS OF INVESTMENT ACTIVITY IN THE CONDITIONS OF THE STRUCTURAL ADJUSTMENT OF THE ECONOMY
}

\section{МЕТОДИЧНІ ОСНОВИ ФОРМУВАННЯ ФОРМ ПРОВЕДЕННЯ ЕФЕКТИВНОЇ ІНВЕСТИЦИЙНОЇ ДІЯЛЬНОСТІ В УМОВАХ СТРУКТУРНОЇ ПЕРЕБУДОВИ ЕКОНОМІКИ}

\section{Zhukov Vladlen ${ }^{1}$ \\ DOI: http://dx.doi.org/10.30525/978-9934-571-28-2_13}

\begin{abstract}
Integration of Ukraine into the global society needs to develop its economy held by the generally accepted principles and laws of the State of economic science. In conditions of transition economy, when the process of overcoming internal crises in the enterprise is complicated by the unstable macro-economic environment, the problem takes on special significance. A generalization of the fundamental works of foreign and domestic scholars on this issue allowed to conclude that the question of methodological and conceptual approaches to solving the problem of organizing the management of the investment activity industrial enterprise has not found a suitable solution as in the scientific and organizational and practical aspects.

The aim of the article is the theoretical rationale and development of methodological approaches and practical recommendations for improving the management of the investment activities of industrial enterprises. To achieve this goal in the article was, and decided the following tasks: identify the organizational-economic features of the regulation of investment activity of industrial enterprises; development of methodical approaches to increase the effectiveness of the use of investment resources. Methodological and theoretical basis of the study is the provision of economic theory, the study of domestic and foreign scholars on the theory of investment entity, assessment of their effectiveness and financial support.
\end{abstract}

\footnotetext{
${ }^{1}$ Candidate of Economic Sciences,

Associate Professor of the Department of Banking,

Simon Kuznets Kharkiv National University of Economics, Ukraine
} 
Scientific novelty of the obtained results is the rationale of new approaches to improve the management of the investment activities of industrial enterprises in the face of economic transformation, namely:

- improved: the concept of "investment" on the basis of the analysis and generalization of theoretical principles and essence of investment activity of industrial enterprises taking into account the features of the transformation of the economy;

- the scheme of interaction of economic, institutional, legal, informational, organizational components of the enterprise strategy, which allow you to have a clear picture of the development and implementation of the investment strategy of the company.

The practical significance of obtained results is that implementation of the suggested proposals and recommendations in practical activity of enterprises is a structured set of several aspects, and in the first place, such as economic, institutional, normative-legal, informational, organizational. These aspects are interdependent, their structuring and allocation of priorities between them allow you to have a clear idea about the design and implementation of the investment strategy of the company.

One of the problems in the formation of the strategy of investment activity of the enterprise is to identify the necessary structural strategic changes, creating an effective organizational form of realization of investment problems. In the meantime, the best approach to the formation of the organizational structure of the enterprise necessary for the exercise of investment activities, is a systemic approach.

Strategy management of investment activity is inextricably linked to the effective use of investment resources. When the resource potential of the investment activity in many respects is defined as the presence of different financial sources necessary for the formation of investment resources and the ability of the enterprise to effectively and efficiently use each of the sources.

\section{1. Вступ}

Інвестування відіграє важливу роль в економіці, визначає значною мірою не тільки стійкий розвиток окремих підприємств, але і є базою, на якій грунтується економічний розвиток суспільства в цілому. Разом 3 тим успішний розвиток підприємства в умовах конкурентного оточення багато в чому залежить від ступеня його інвестиційної активності. При цьому прагнення підприємства не тільки вижити, але й одержати доход, 
достатній для відновлення і приросту економічного потенціалу, повинно спонукати підприємства шукати напрямок ефективного вкладення власних коштів і залучати інвесторів 3 метою створення індивідуальних переваг перед конкурентами в конкретній сфері виробництва.

Тому в основі інвестиційної діяльності будь-якого підприємства повинна знаходитися певна стратегія, що визначає цілі і задачі господарської структури в даній сфері діяльності. У той же час інвестиційна стратегія розробляється відповідно до загальних стратегічних задач, що постають перед підприємством. Це пов'язано з тим, що будь-який вид діяльності підприємства підпорядкований загальній стратегії, що має на увазі визначення довгострокових задач, прийняття курсу дій і розподіл ресурсів, необхідних для виконання поставлених цілей.

Теоретичні аспекти та проблеми здійснення інвестиційної стратегії роз-робляються відповідно до загальних стратегічних задач досліджувались як у зарубіжній, так і в вітчизняній літературі таких провідних учених-економістів: Путятин Ю.А., Фатхутдинов Р.А., Евенко Л.И., Овсиевич Б.Л., Оучи У., Беа Ф., Забродский В.А., Дихтла Э., Швайцера М., Пономаренко В.С., Виханский О.С., Ковалев В.В. та багатьох інших. При цьому у даних наукових працях розглядаються питання фінансування окремих інвестиційних проектів, однак у нинішніх ринкових умовах необхідно забезпечити подальше вивчення та обгрунтування методичних основ формування форм проведення ефективної інвестиційної діяльності в умовах перебудови економіки.

Мета статті - обгрунтувати напрями удосконалення методики проведення ефективної інвестиційної діяльності в умовах структурної перебудови економіки.

\section{2. Особливості формування інвестиційної стратегії підприємства}

Слід зазначити, що комплексні дослідження і розробку інвестиційної стратегії доцільно проводити тільки у взаємозв'язку з головними цілями функціонування підприємства. При цьому формування інвестиційної стратегії є трудомістким процесом, тому що перш за все вона повинна базуватися на прогнозуванні окремих умов здійснення інвестиційної діяльності (інвестиційного клімату) і кон'юнктурі інвестиційного ринку. Складність цього процесу полягає в тому, що він вимагає ретельного пошуку і оцінки альтернативних варіантів інвестиційних рішень, що найповніше відповідають підприємству і перспективам 
його розвитку. Особливості формування інвестиційної стратегії полягають також у тому, що вона не є незмінною, а вимагає періодичного коректування з урахуванням мінливих зовнішніх і внутрішніх умов іiі реалізації (рис. 1).

Прийняття раціональних інвестиційних рішень грунтується на викорис-танні різного роду кількісних і якісних показників оцінки доцільності реалізації тих чи інших проектів. Разом з тим формування інвестиційної стратегії, як і будь-якого багатогранного поняття, не вичерпується лише простим порівнянням певного набору показників, тому що інвестиційна стратегія з погляду стратегічного менеджменту $[1 ; 2 ; 3]$, є структурованою сукупністю декількох аспектів, у першу чергу таких, як економічний, інституційний, нормативно-правовий, інформаційний.

Ці аспекти є взаємозалежними, їх структурування і розподіл пріоритетів між ними дозволяють мати чітке уявлення про розробку i реалізацію інвестиційної стратегії підприємства. Слід зазначити, що доцільність розгляду стратегії управління інвестиційною діяльністю підприємства у вигляді структурованої сукупності різних аспектів ситуаціях і для вирішення будь-яких задач..

Як було зазначено вище, інвестиційна діяльність підприємства повинна будуватися на основі інвестиційної стратегії, яка розробляється з використан-ням різних фінансово-економічних методів, що у сукупності складають науково-фінансову методологію формування інвестиційної стратегії і являють собою економічний аспект інвестиційної стратегії. Базовими елементами економічного аспекту є сукупність різних економічних показників, що використовуються для оцінки інвестиційної стратегії. Наприклад, це можуть бути такі показники:

- обсяг випуску продукції;

- структура випуску продукції;

- динаміка реалізації готової продукції;

- динаміка інвестиційних витрат і доходів;

- строк окупності інвестиційних рішень тощо.

Поряд 3 цим економічний аспект також потребує вибору певних мето-дів і підходів до управління інвестиційною діяльністю, що дозволяють про-водити:

- аналіз можливостей підприємства для здійснення конкретних видів інвестиційної діяльності; 


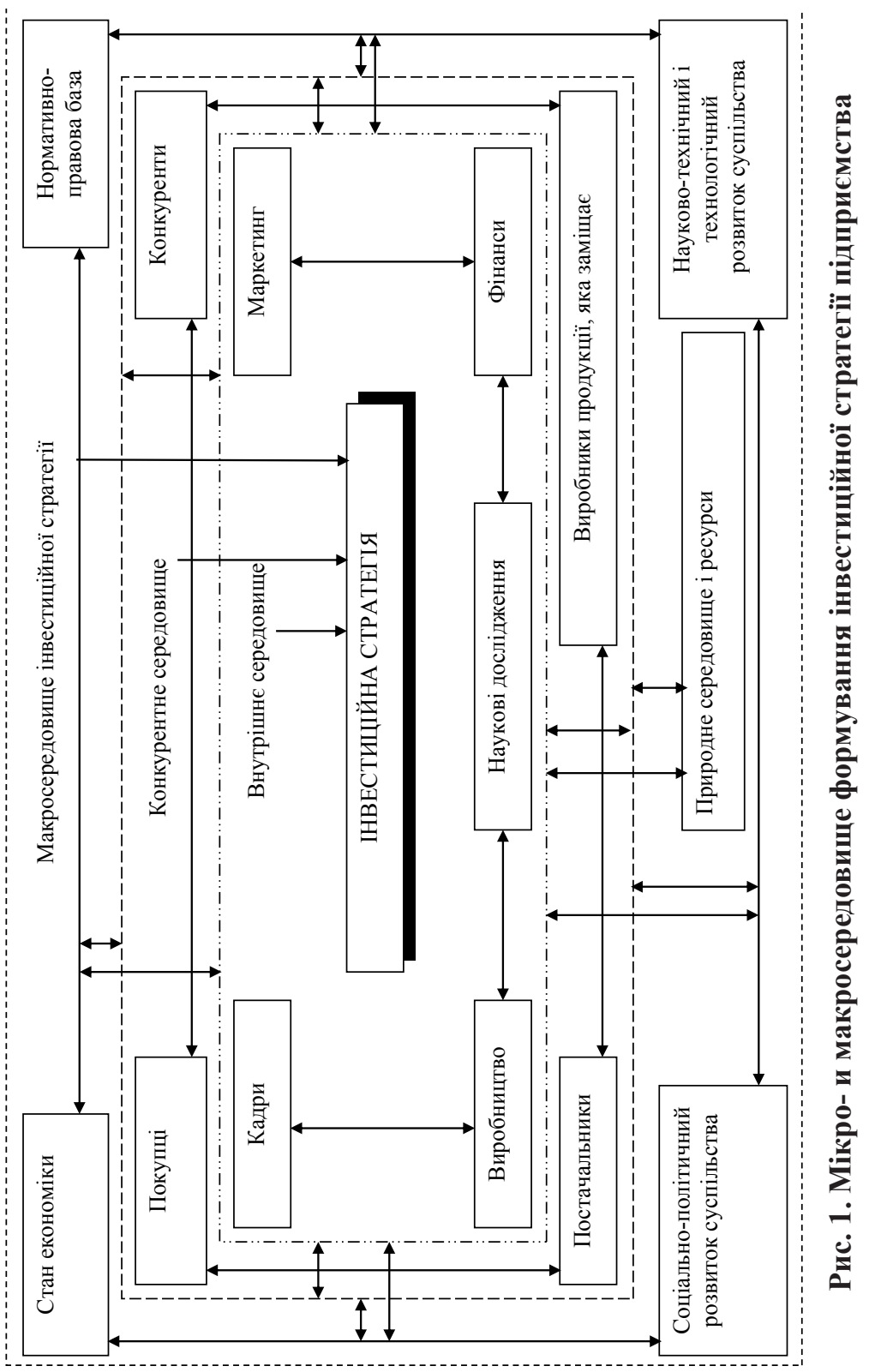


- планування інвестиційної діяльності;

- оперативне втручання і регулювання окремих етапів інвестиційної діяльності, що є особливо актуальним в період структурної перебудови;

- контроль за виконанням прийнятих рішень і т. ін.

У рамках інституційного аспекту інвестиційної стратегії здійснюється вибір інвестицій визначеного виду, формується інвестиційний портфель, оцінюється ризик проведення конкретних етапів і напрямків інвестиційної діяльності.

Нормативно-правовий аспект інвестиційної стратегії є взаємодією таких складових:

- законодавчі і нормативно-правові акти на рівні держави, що утворюють юридичну основу і формують фіскальне середовище, у рамках яких підприємство формує інвестиційну стратегію і здійснює інвестиційну діяльність;

- внутрішні регулюючі документи підприємства, що дозволяють забезпечувати безперервність інвестиційної діяльності в рамках усього підприємства.

Інформаційний аспект інвестиційної стратегії являє собою систему обробки інформації, що є базисом інформаційного обміну в рамках інвестиційної стратегії, дозволяє оперативно реагувати на зміни в юридичних установах і фіскальному середовищі, прогнозувати економічні перспективи ринків і планувати зміни в межах інституційного аспекту, коректувати певні частини інвестиційної стратегії.

Разом 3 тим, поряд 3 вище розглянутими питаннями, на погляд автора, важливим є управління організаційним аспектом проведення інвестиційної діяльності, тобто необхідно враховувати, наскільки структура підприємства сприяє досягненню поставлених цілей для реалізації стратегічних рішень підприємства, у тому числі й у сфері інвестиційної діяльності. Так, на думку Кнута Бляйхера, «організаційна політика як частина загальної концепції підприємства забезпечує його здатність до виживання і розвитку і стає, таким чином, відправною точкою конкретної організаційної діяльності у фазах планування, підготовки, реалізації і контролю прийнятих рішень» [4]. При цьому суть стратегічного управління полягає в тому, що на підприємстві, з одного боку, існує чітко організоване комплексне стратегічне планування з іншого, - організаційна структура управління підприємством адекватна «формальному» стратегічному плануванню [1]. 


\section{Zhukov Vladlen}

Суттєвим є і той факт, що розробка певної інвестиційної стратегії також впливає на формування організаційної структури підприємства, тому що в загальному плані стратегічне управління підприємством це орієнтована на майбутнє організаційна структура в межах концепції пристосованості підприємства до умов, що змінюються [5; 6]. Під організацією автор розуміє процес цілеспрямованої цілісної структуризації, а під організаційною структурою - різні типи і форми відносин між складовими елементами підприємства. Наприклад, відносини розподілу, що виникають через взаємозалежний розподіл задач, матеріальних і людських ресурсів при збиранні автомобілів, мають форму супідрядності, організаційна структура якої може бути подана лінійним типом.

У той же час організаційні принципи побудови підприємства визначаються його цілями і стратегією. Задача будь-якого підприємства полягає в досягненні цілей, для яких воно було створене. Ефективність вирішення такої задачі полягає в досягненні мети в конкретно обумовлені проміжки часу і при найменших витратах. Однак під впливом зміни споживчого попиту, високих темпів науково-технічного прогресу, збільшення масштабів і ускладнення виробництва, обмеженості ряду ресурсів і інших факторів може змінюватися характер і напрямки цілей, змінюються способи їх досягнення. Тому організаційні структури не тільки можуть змінюватися, але і повинні мати певну гнучкість і пристосованість. Разом з тим, розглянуті вище аспекти дозволяють формувати найбільш ефективні інвестиційні стратегії, пов'язані 3 розвитком підприємства, в умовах зміни зовнішнього і внутрішнього середовища, що сприяє вирішенню певних інвестиційних задач.

Інформаційний і організаційний аспекти дозволяють якнайкраще досягти погодженості інвестиційної стратегії підприємства із загальною стратегією його економічного розвитку. За рахунок додавання 3 урахуванням інституційного аспекту забезпечується внутрішня збалансованість інвестиційної стратегії. При цьому на основі економічної і нормативно-правової оцінки досліджується погодженість цілей, напрямків і етапів реалізації тих чи інших стратегій для різних напрямків діяльності підприємства. У процесі такої оцінки визначається, наскільки узгоджуються між собою окремі стратегічні цілі і напрямки інвестиційної діяльності, а також послідовність їхнього виконання. Взаємодія і взаємозв'язок інвестиційної стратегії з зовнішнім середо- 
вищем забезпечується нормативно-правовим аналізом на основі наявної інформації. При цьому також оці-нюється, наскільки розроблена інвестиційна стратегія відповідає прогнозова-ним змінам економічного розвитку й інвестиційного клімату країни, а також кон'юнктури інвестиційного ринку.

Поряд 3 цим найкраща реалізованість інвестиційної стратегії досягається за рахунок використання найбільш ефективної організаційної структури, що базується на урахуванні наявного ресурсного потенціалу підприємства. У процесі такої оцінки повинні бути проаналізовані потенційні можливості підприємства у формуванні фінансових ресурсів, оцінена кваліфікаційна підготовленість персоналу і технічна оснащеність підприємства 3 позицій задач реалізації інвестиційної стратегії. Також розглядається необхідність і можливість залучення до реалізації інвестиційної стратегії необхідних фінансових, технологічних, сировинних, енергетичних і інших ресурсів.

Розглянуті вище аспекти інвестиційної стратегії також дозволяють оцінити прийнятний рівень ризику, можливі фінансові наслідки результативності інвестиційних програм.

Таким чином, інвестиційна стратегія підприємства може бути подана у вигляді єдиної інтегрованої системи, що включає в себе економічний, інститу-ційний, нормативно-правовий, інформаційний і організаційний аспекти, що тісно пов'язані між собою критерієм досягнення головної мети підприємства. Слід також зазначити, що організаційний аспект зумовлює і напрямок руху інформаційних потоків між різними складовими елементами інвестиційної стратегії підприємства, що також впливає на ефективність формованої стратегії, яка формується, визначає тактику проведення інвестиційної діяльності.

При цьому вибір організаційної структури багато в чому визначається тими питаннями, які необхідно вирішити підприємству для досягнення поставлених інвестиційних задач і існуючих обмежень, що перешкоджають їх ефективному вирішенню. Однак, незважаючи на безліч проблем, які мають підприємства в процесі здійснення тих чи інших інвестиційних проектів, виділяють такі підходи, що лежать в основі визначення ефективної структури організації [7; 8]:

- орієнтація на вирішення конкретної інвестиційної задачі, що дозволяє в межах організаційного синтезу здійснювати розподіл окремих 


\section{Zhukov Vladlen}

підзадач інвестиційної діяльності по організаційних одиницях - ділянках, відділах, групах;

- орієнтація на особистість, де предметом дослідження стають елементи організаційних правил, пов'язаних з питаннями первинної мотивації, комунікацією, лідерством і ін.;

- орієнтація на інформаційну технологію, метою якої є своєчасне забезпечення достовірною інформацією всього процесу управління інвестиційною діяльністю.

Перераховані вище підходи є основою для побудови простих, як правило, лінійних організаційних структур. У лінійній структурі від кожного вищого керівника виходять вказівки підлеглим керівникам i виконавцям. Різновидом лінійних структур $є$ лінійно-штабна структура, що припускає автономне вирішення деяких задач під керівництвом загального центру. Недоліком лінійної організаційної структури $\epsilon$ тривалість у виконанні прийнятих рішень. Компенсувати ці недоліки допомагають багатолінійні (матричні) структури, у яких розподіл повноважень і прийняття рішень здійснюється у відповідності із специфікою рівнозначних спеціалізованих задач. Їх характерною рисою $є$ накладання на загальну вертикальну ієрархію деякої сукупності горизонтальних повноважень і комунікацій. У цілому матричні структури розподіляються таким чином:

- проектні - структури 3 динамічною горизонтальною системою супідрядності;

- продуктові, - горизонтальні системи управління виробництвом продукції передбачають створення матричних структур з «постійним положенням»;

- внутрішньофункціональні, - матричні механізми управління застосовуються на рівні окремих функцій і підрозділів.

Оскільки підприємство не може існувати поза складними і динамічними відносинами із зовнішнім середовищем, для вирішення задачі формування стратегії і тактики управління інвестиційною діяльністю необхідно розгляну-ти більш складні підходи, які застосовуються для визначення ефективної структури організації. Основу таких підходів складають уявлення про підприємство як про складну виробничу операційну систему, кінцевим продуктом стратегічного управління якої є внутрішня структура й організаційні зміни, що забезпечують чутливість підприємства до змін у зовнішньому середовищі. 


\section{Methodological basis of the formation of effective forms of investment...}

Таким чином, стратегічне управління інвестиційною діяльністю підпри-ємства спрямоване на забезпечення стратегічної позиції, що повинна забезпечити тривалу життєздатність підприємства в умовах, що змінюються. Отже, однією з задач при формуванні стратегії інвестиційної діяльності підприємства є виявлення необхідності проведення структурних стратегічних змін, створення ефективної організаційної форми реалізації інвестиційних задач.

Проведення всебічного аналізу організаційної структури для формування ефективної стратегії проведення інвестиційної діяльності можна здійснити з позицій концепції прийняття рішень. Ця концепція, основоположниками якої вважаються Р. Сайман, Д. Маргем і Р. Сайєрт, припускає, що в основі вивчення організаційних процесів повинно знаходитися «рішення» - акт цілеспрямованого вибору чи усунення деякої проблеми [7]. Однак для того щоб прийняти потрібне рішення, необхідно, як мінімум, знати вихідну (існуючу) структуру організації і ту структуру організації, що, з одного боку, визначається навкруги поставлених інвестиційних задач, а з іншого - здатна забезпечити виконання поставлених задач. Досягнення поставленої мети можливе за рахунок ситуаційного аналізу, за допомогою якого на основі порівняльних емпіричних даних дається опис впливу факторів зовнішнього середовища і підприємства на окремі параметри структури організації.

Як показує, проведений аналіз ряду теоретичних робіт в галузі організаційних структур $[1 ; 4 ; 5 ; 6 ; 8 ; 9 ; 10 ; 11]$, за основні параметри, з допомогою яких, на думку автора, може бути проведений аналіз організаційної структури вирішення задачі формування стратегії управління інвестиційною діяльністю підприємства (принаймні для існуючих умов господарювання), необхідно вибрати:

- ступінь забезпеченості підприємства фінансовими ресурсами для вирішення поставлених інвестиційних задач;

- ступінь інноваційної результативності інвестиційних задач підприємства, що припускає, у першу чергу, рівень створеної продукції і можливість їі конкурентоспроможності;

- тимчасову тривалість інвестиційного проекту;

- загальний ризик виконання інвестиційного рішення;

- вид орієнтації інвестиційного рішення - кадрова, об'єктна й інформаційна; 


\section{Zhukov Vladlen}

- нормативно-правову забезпеченість прийнятих інвестиційних рішень;

- рівень прийняття і реалізації управлінських рішень.

Проте застосування ситуаційного підходу для вирішення задачі форму-вання стратегії управління інвестиційною діяльністю утруднене тим, що вплив окремих параметрів на вибір визначеної організаційної структури не завжди можна оцінити однозначно.

\section{3. Системні підходи для визначення структури організації}

Для вирішення такої задачі, як правило, використовують системні підходи для визначення структури організації [7; 12], у рамках яких підприємство і зовнішнє середовище, в якому воно функціонує, розглядають як єдине ціле. Поряд з цим підприємство в цих підходах подається як мережа вирішальних центрів, пов'язаних між собою і 3 зовнішнім середовищем комунікаційними каналами (відділ збуту підприємства - потенційні покупці; плановий відділ, бухгалтерія, податкові служби, відділ роботи з інвесторами і кредиторами і та інші). При такому підході структура організації орієнтована на процес прийняття рішень, мотивацію і контроль.

Разом $з$ тим системний підхід заснований на тому, що в організаційних системах поведінка будь-якої частини врешті-решт впливає на всі інші частини. Однак не усі впливи істотні, частину з них неможливо знайти. Тому за одиниці виміру, що характеризують зміну розглянутих вище параметрів, доцільно використовувати так звані «лінгвістичні» змінні, котрі описують якісні сторони обраних параметрів. Якісна характеристика параметрів, запропонована автором, подана в табл. 1. Переваги такого підходу полягають у тому, що система поданих показників і їх характеристик є відкритою і може бути доповнена і змінена як у розрізі розв'язуваної інвестиційної задачі, так і з урахуванням тимчасового фактора (система показників і їх характеристик з часом може видозмінюватися).

Наочне відображення існуючої організаційної структури (відбиваються ті умови, що склалися на підприємстві в момент проведення відповідного аналізу) і необхідної організаційної структури для досягнення поставлених інвестиційних задач можна уявляти за допомогою пелюсткової діаграми, де на кожній осі розташовані якісні характеристики розглянутих параметрів. Така діаграма в загальному вигляді являє собою формальний опис організаційної структури підприємства і вказує ступінь 
відповідності між існуючими і необхідними умовами формування визначеної інвестиційної стратегії підприємства.

На рис. 2 подано діаграму, яка відображає існуючу і необхідну організаційну структуру для ефективного управління інвестиційною діяльністю, що спрямована на виробництво нових видів товарів на підприємстві. Тут осі 1, 2, ., 7 відповідають параметрам проведення аналізу організаційної структури підприємства, що подані в табл. 1. Кожна 3 осей має мітки 1, 2, 3, які відбивають якісні характеристики кожного 3 параметрів. Наприклад, вісь 1 відповідає забезпеченості підприємства фінансовими ресурсами. Мітки по цій осі означають 1 - незадовільна забезпеченість, 2 - задовільна забезпеченість, 3 - достатнє забезпечення (див. табл. 1).

За основу були обрані узагальнені результати опитування керівників різних рівнів. Вид опитувальних листків подано у табл. 2. Опитування проводилося відповідно до якісних характеристик параметрів, поданих у табл. 1 різних рівнів підприємства.

Основними напрямками, необхідними для досягнення бажаних результатів у сфері виробництва нових видів техніки у підприємства, є:

- достатня забезпеченість підприємства фінансовими ресурсами;

- автономна система управління орієнтована на прийняття самостійних рішень.

Виходячи $з$ аналізу рис. 2, можна припустити, що при формуванні стратегії управління інвестиційною діяльністю підприємства основну увагу варто приділити удосконаленню організаційної структури управління і прийняттю оперативних рішень на рівні окремих підрозділів за рахунок надання їм деякої самостійності, а також удосконаленню тактики управління залученням фінансових ресурсів. Разом 3 тим, як було зазначено вище, найкраща результативність інвестиційних рішень досягається за рахунок використання найбільш ефективної організаційної структури. Тому, далі необхідно докладніше зупинитись на вирішенні першого питання.

Як було зазначено вище, найкращим підходом у формуванні організаційної структури підприємства, необхідним для здійснення інвестиційної діяльності, є системний підхід. У той же час найбільш ефективною формою організаційної структури управління є матрична модель, за допомогою якої, зокрема, і можна організувати автономну систему управління, орієнтовану на прийняття самостійних рішень. Вибір 


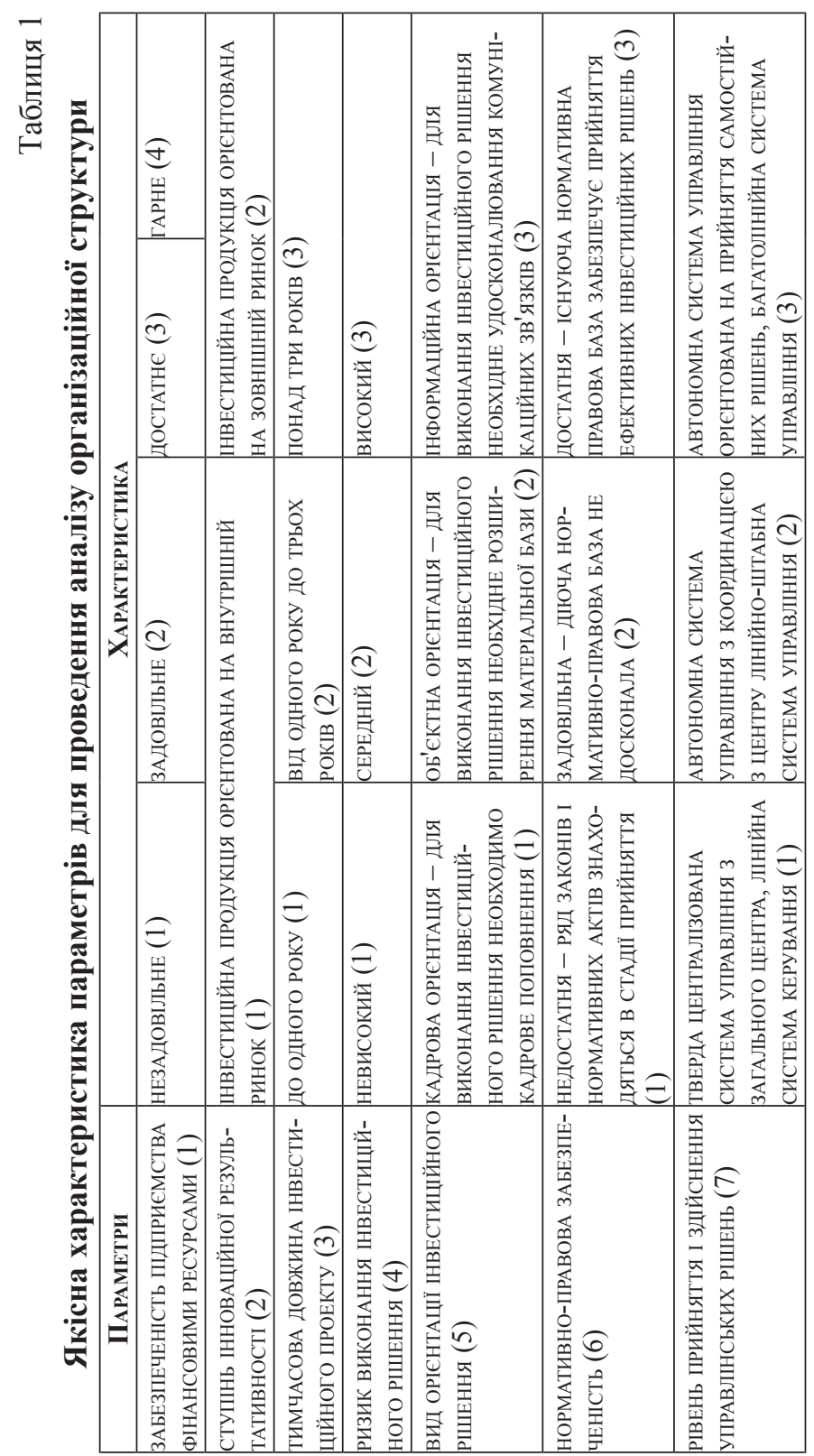


Таблиця 2

Опитувальний лист для побудови формального опису існуючої і необхідної організаційної структури підприємства для реалізації інвестиційних рішень, спрямованих на виробництво нових видів сільськогосподарської техніки

\begin{tabular}{|l|l|}
\hline \multicolumn{1}{|c|}{ Параметри опитування } & \multicolumn{1}{|c|}{$\begin{array}{c}\text { Характеристика } \\
\text { (існуюча/необхідна) }\end{array}$} \\
\hline $\begin{array}{l}\text { Яка, на вашу думку, забезпеченість підприємства } \\
\text { фінансовими ресурсами. Варіанти відповідей 1-4 } \\
\text { згідно з табл. 1. }\end{array}$ & Незадовільне/Достатнє \\
\hline $\begin{array}{l}\text { Основні ринки, для яких призначена інвести- } \\
\text { ційна продукція. Варіанти відповідей 1-2 згідно } \\
\text { з табл. } 1 .\end{array}$ & $\begin{array}{l}\text { Внутрішній ринок/ } \\
\text { Внутрішній ринок }\end{array}$ \\
\hline $\begin{array}{l}\text { Яким має бути період освосння інвестиційної про-- } \\
\text { дукції. Варіанти відповідей 1-3 згідно з табл. 1. }\end{array}$ & $\begin{array}{l}\text { Від одного до трьох років/ } \\
\text { Від одного до трьох років }\end{array}$ \\
\hline $\begin{array}{l}\text { Який ризик не виконання інвестиційних рішень. } \\
\text { Варіанти відповідей 1-3 згідно з табл. 1. }\end{array}$ & Середній/Середній \\
\hline $\begin{array}{l}\text { Які головні умови (крім фінансових), необхідні } \\
\text { для виконання інвестиційних рішень. Варіанти } \\
\text { відповідей 1-3 згідно з табл. 1. }\end{array}$ & $\begin{array}{l}\text { Необхідно кадрове поповнення/ } \\
\text { Необхідно кадрове поповнення }\end{array}$ \\
\hline $\begin{array}{l}\text { Яка нормативно-правова забезпеченість ефектив- } \\
\text { ного виконання інвестиційних рішень. Варіанти } \\
\text { відповідей 1-3 згідно з табл. 1. }\end{array}$ & Задовільне/Задовільне \\
\hline $\begin{array}{l}\text { Який рівень прийняття і виконання управлін- } \\
\text { ських рішень. Варіанти відповідей 1-3 } \\
\text { згідно з табл. 1. }\end{array}$ & 2/3 \\
\hline
\end{tabular}

матричної організаційної структури управління також обумовлений таким:

по-перше, існуючі умови господарювання визначили дуже високі вимоги в цілому до системи управління підприємством, що виявляється в необхідності вирішення цілого комплексу взаємозалежних задач;

по-друге, цілий ряд задач у сфері управління інвестиційною діяльністю має рівнозначне значення. Це і формування необхідної структури фінансового забезпечення інвестиційної діяльності, і організація виробництва готової про-дукції з найменшими витратами й успішною реалізацією виробленої про-дукції;

по-третє, підвищенням інформаційного перенавантаження простих систем управління і значимістю інформаційної складової в системі управління інвестиційною діяльністю; 

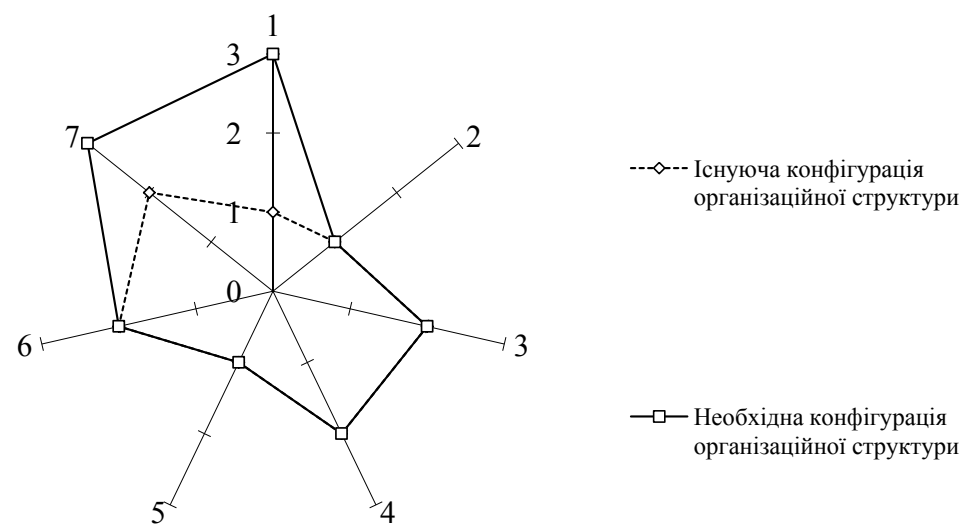

$\longrightarrow$ - Необхідна конфігурація організаційної структури

\section{Рис. 2. Формальний опис організаційної структури підприємства}

по-четверте, матрична організаційна структура системи управління голо-вним чином лише змінює повноваження і відповідальність існуючих служб і підрозділів, а не породжує істотно нових підрозділів.

На рис. 3 подано матричну організаційну структуру системи управління інвестиційною діяльністю підприємства, що розроблена автором і запропонована для впровадження на підприємстві. Виходячи 3 основних напрямків, необхідних для успішної реалізації інвестиційної діяльності в сфері виробництва нових видів техніки, у складі окремих структурних одиниць виділені такі відділи:

- відділ по роботі з науковими організаціями, що сприяе активізації роботи конструкторського відділу, систематизації існуючих розробок у сфері виробництва нових видів сільськогосподарської техніки; мінімізації витрат на придбання ліцензій на використання винаходів, прав на патенти, послуг технологічного змісту тощо, що загалом повинно сприяти більш раціональному використанню фінансових ресурсів;

- відділ по роботі з кредиторами й інвесторами, необхідний для безпосереднього забезпечення інвестиційної діяльності підприємства необхідним обсягом фінансових коштів, вирішення ряду оперативних питань, що виникають у процесі реалізації тактичних задач фінансового забезпечення інвестиційної дія-льності підприємства; 


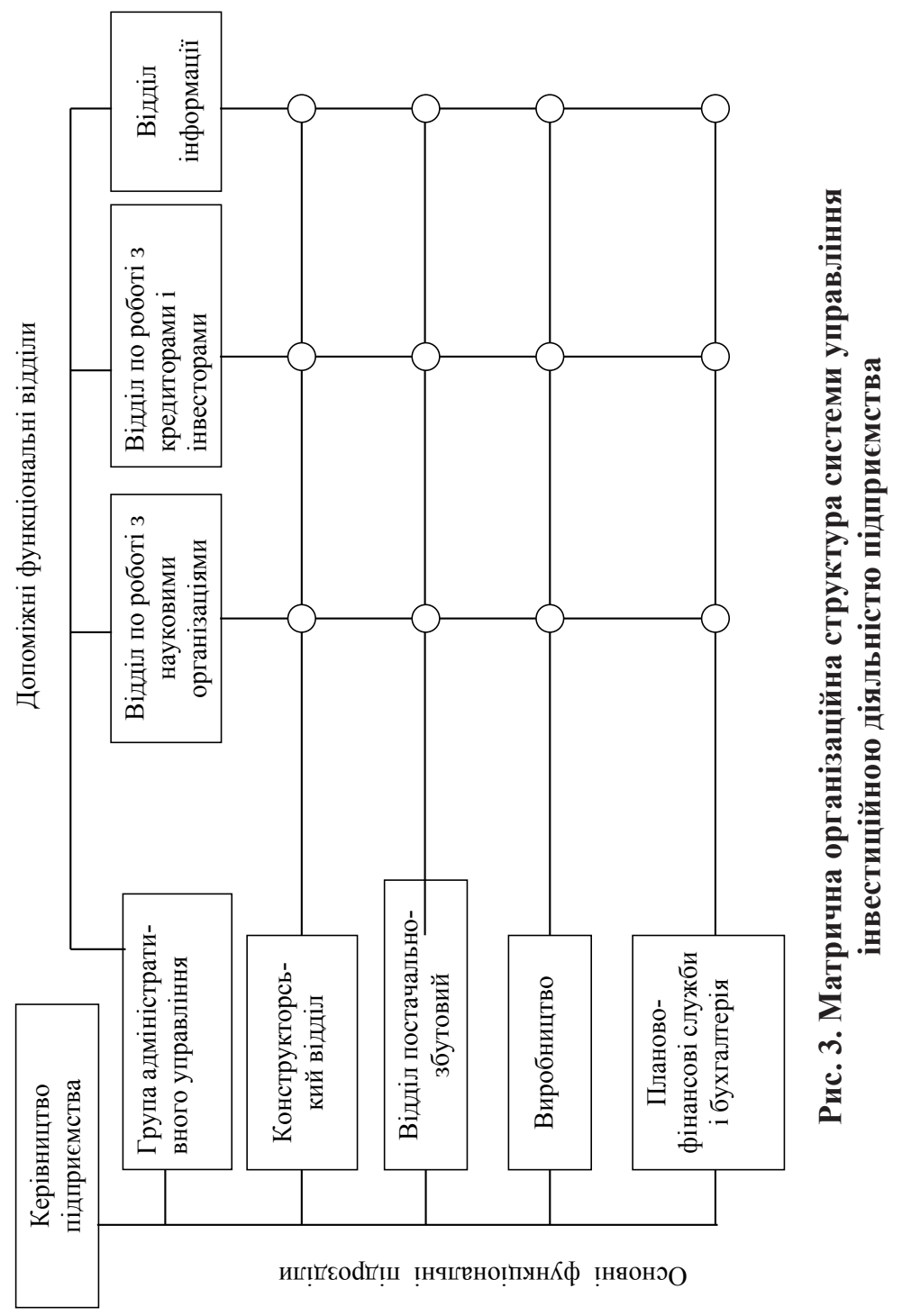




\section{Zhukov Vladlen}

- відділ інформації, що забезпечує удосконалення системи управління інвестиційною діяльністю підприємства на етапах забезпе-чення виробництва матеріальними ресурсами і реалізації готової продукції, систематизації різних джерел даних про ринки сировини і збуту готової продукції, конкурентах; всебічного аналізу маркетингової інформації.

Особливості даної структури полягають у такому:

- стратегічне управління інвестиційною діяльністю підприємства здійснює генеральний директор підприємства і його заступники;

- управління на тактичному рівні здійснює адміністративна група, до складу якої входять керівники основних підрозділів;

- оперативне управління здійснюється за допомогою допоміжних функціональних відділів, що безпосередньо підпорядковуються групі адміністративного управління.

За рахунок такого структурування, сполучення різних рівнів управління (стратегічного, тактичного й оперативного) досягаються:

- найкраща мобільність і автономність управління інвестиційною діяльністю;

- ефективне і раціональне використання інвестиційного потенціалу підприємства;

- збалансованість у прийнятті і реалізації управлінських рішень;

- ширше охоплення й урахування різних факторів, що впливають на інвестиційну стратегію підприємства при розробці конкретних управлінських рішень;

- оперативна гнучкість у реагуванні на зміну зовнішніх і внутрішніх факторів ринкової кон'юнктури;

- найбільш послідовний перехід до ринкової стратегії управління інвестиційною діяльністю пов'язаний $з$ перебудовою всієї системи розподілу ресурсів і внутрішньофірмового планування.

\section{4. Висновки}

Інвестиційна стратегія підприємства є структурованою сукупністю декількох аспектів, і в першу чергу таких, як економічний, інституційний, нормативно-правовий, інформаційний, організаційний. Ці аспекти є взаємозалежними, їхнє структурування і розподіл пріоритетів між ними дозволяють мати чітке уявлення про розробку і реалізацію інвестиційної стратегії підприємства. 
Однією із задач при формуванні стратегії інвестиційної діяльності підприємства є виявлення необхідності проведення структурних стра-тегічних змін, створення ефективної організаційної форми реалізації інвестиційних задач. У той же час кращим підходом до формування організаційної структури підприємства, необхідної для здійснення інвестиційної діяльності, є системний підхід.

Формування стратегії управління інвестиційною діяльністю не-розривно пов'язане з ефективним використанням інвестиційних ресурсів. При цьому ресурсний потенціал інвестиційної діяльності підприємства багато в чому визначається як наявністю різних фінансових джерел, необхідних для формування інвестиційних ресурсів, так і здатністю підприємства ефективно і раціонально використовувати кожне із джерел.

\section{Список літератури:}

1. Ansoff I. Implanting Strategy Management / I. Ansoff - Englewood Cliffs. 1984. $-516 \mathrm{p}$.

2. Путятин Ю. А. Финансовые механизмы стратегического управления развитием предприятия / Ю.А. Путятин, А.И. Пушкарь, А.Н. Тридед Харьков: Основа, 1999. -488 с.

3. Ковалев В.В. Финансовый анализ: Управление капиталом. Выбор инвестиций. Анализ отчетности / В.В. Ковалев - М.: Финансы и статистика, 1996. $-432 \mathrm{c}$.

4. Bleicher Knut. Organisation - Strukturen / K. Bleicher - Kulturen -Wies baden. $-1991 .-487 \mathrm{p}$.

5. Виханский О.С. Стратегическое управление / О.С. Виханский - М.: Изд. МГУ. $-1995 .-360$ с.

6. Пономаренко В.С. Стратегічне управління підприємством / В.С. Пономаренко - Х.: Основа, 1999. - 620 с.

7. Беа Ф. Экономика предприятия / Ф. Беа, Э. Дихтла, М. Швайцера - М.: ИНФРА-М. - 1999. - 928 с.

8. Оучи У. Методы организации производства (японский и американский подходы) / У. Оучи - М. - Экономика. - 1984. - 316 с.

9. Забродский В.А. Современные методы организации и управления промышленным производством / В.А Забродский, Н.А Кизим, Л.И. Янов Харьков: Бизнес-Информ. - 1997. - 64 с.

10. Овсиевич Б.Л. Модели формирования организационных структур / Б.Л. Овсиевич - М.: - Наука. - 1979. - 178 с.

11. Евенко Л.И. Организационные структуры управления промышленными корпорациями США / Л.И. Евенко - М.: Наука. - 1983. - 352 с.

12. Фатхутдинов Р.А. Стратегический менеджмент / Р.А. Фатхутдинов Москва: 3АО «Бизнес-школа «Интел-Синтез». - 1998. - 416 с. 


\section{Zhukov Vladlen}

\section{References:}

1. Ansoff I. (1984) Implanting Strategy Management - Englewood Cliffs.

2. Putyatin Yu.A., Pushkar A.I., Trided A.N. (1999) Finansovye mekhanizmy strategicheskogo upravleniya razvitiem predpriyatiya [Financial arrangements for the strategic management of development of the enterprise]. - Kharkov: Osnova. (in Ukrainian)

3. Kovalev V.V. (1996) Finansovyy analiz: Upravlenie kapitalom. Vybor inve-stitsiy. Analiz otchetnosti [Financial analysis: asset management. Choice of investments. Analysis reporting]. - Moscow: Finansy i statistika. (in Russian)

4. Bleicher Knut (1991) Organisation - Strukturen - Kulturen -Wies - baden.

5. Vikhanskiy O.S. (1995) Strategicheskoe upravlenie [Strategic management]. - Moscow: Izd. MGU. (in Russian)

6. Ponomarenko V.S. (1999) Strategichne upravlinnya pidpricmstvom [Strategic enterprise management]. - Kharkov: Osnova. (in Ukrainian)

7. Bea F., E. Dikhtla, M. Shvaytsera (1999) Ekonomika predpriyatiya [Economics of enterprise]. - Moscow: INFRA-M. (in Russian)

8. Ouchi U. (1984) Metody organizatsii proizvodstva (yaponskiy $i$ amerikanskiy podkhody [Methods of organizing production (japanese and american approaches)]. - Moscow: Ekonomika. (in Russian)

9. Zabrodskiy V.A., Kizim N.A, Yanov L.I. (1997) Sovremennye metody organizatsii $i$ upravleniya promyshlennym proizvodstvom [Modern methods of organization and control of industrial production]. - Kharkov: Biznes-Inform. (in Ukrainian)

10. Ovsievich B.L. (1979) Modeli formirovaniya organizatsionnykh struktur [Models of formation of organizational structures]. - Moscow: - Nauka. (in Russian)

11. Evenko L.I. (1983) Organizatsionnye struktury upravleniya promyshlennymi korporatsiyami SShA [Organizational management structure of industrial corporations United States]. - Moscow: Nauka. (in Russian)

12. Fatkhutdinov R.A. (1998) Strategicheskiy menedzhment [Strategic management]. - Moscow: ZAO «Biznes-shkola «Intel-Sintez». (in Russian) 